\title{
Asisoasi Pergeseran Leksikon dalam Tuturan Masyarakat Pesisir di Jepara
}

\author{
Riris Tiani \\ Fakultas Ilmu Budaya, Universitas Diponegoro, Semarang \\ tiani.riris@gmail.com
}

\begin{abstract}
This study of the lexicon and the cultural values contained in the lexicon 'pergi' in the Javanese dictionary. The purpose of this study was to identify the Javanese lexicon for the mention of lexicon 'pergi ' and the function of the speech in the coastal communities of Jepara. The approach used is phenomenological context with the semantic anthropology. The data obtained was conducted by in-depth interviews with representatives of the coastal communities of Jepara. The results of this study were the lexicon variations 'pergi' in the coastal communities of Jepara. Cultural heritage in the form of language is realized through the lexicon 'pergi', such as minggat, menyang, budal, tindak, lunga, kesah, mbedal, mlancong, menyat. The 'pergi' lexicon in Javanese has explicit and implied meaning. The anthropological meaning of the 'pergi' lexicon is distinguished by: (1) the context, (2) the speech partner, (3) the mastery of the language of the speaker and the speech partner, and (4) the level of education of the speaker and partner.
\end{abstract}

Keywords : Culture, speech, lexicon.

\section{Intisari}

Studi ini tentang leksikon dan nilai budaya yang terkandung dalam leksikon 'pergi' dalam kamus bahasa Jawa. Tujuan penelitian ini adalah untuk mengidentifikasi leksikon Jawa untuk penyebutan leksikon 'pergi' dan fungsi tuturan tersebut di masyarakat pesisir Jepara. Pendekatan yang digunakan adalah kontekstual fenomenologis dengan ranah semantik antropologi. Pemeroleh data dilakukan dengan wawancara mendalam pada perwakilan masyarakat pesisir Jepara. Hasil penelitian tersebut adalah variasi leksikon 'pergi' pada masyarakat pesisir Jepara. Warisan budaya dalam bentuk bahasa direalisasikan melalui leksikon 'pergi', seperti minggat, menyang, budal, tindak, lunga, kesah, mbedal, mlancong, menyat. Leksikon 'pergi' dalam bahasa Jawa mempunyai makna tersurat dan tersirat. Makna antropologis leksikon 'pergi' dibedakan atas:(1) konteksnya, (2) mitra tutur, (3) penguasaan bahasa penutur dan mitra tutur, dan (4) tingkat pendidikan penutur dan mitra tutur.

Kata Kunci: Budaya tutur, pesisir Jepara, leksikon 'pergi'

\section{Pendahuluan}

Dalam sejarah perkembangan Indonesia, leksikon 'pesisir' tidak pernah bisa diabaikan. Sebab, sebagaimana telah diketahui, sejarah masuknya Islam di Indonesia selalu berawal dari komunitas nelayan dan para pedagang yang sebagian besar terkosentrasi di daerah pantai sekitar wilayah lautan Nusantara. 
Leksikon "pesisir" dalam penelitian ini digunakan untuk mereprsentasikan masyarakat yang tinggal di wilayah pesisir. Istilah ini sangat melekat pada masyarakat yang tinggal dan berbatasan langsung dengan pantai. Masyarakat pesisir (coastal community) memiliki latar belakang ekonomi mengandalkan penghidupan dari sumber daya laut, dan jikalau ada alat produksi biasanya berupa perahu, dengan sistem ekonomi yang hierarkis seperti ada juragan kapal, tengkulak, buruh, nelayan tradisional. Masyarakat pesisir tampak pada kehidupan masyarakat Jawa di Kabupaten Jepara, yang terletak di ujung utara pesisir Jawa.

Sejumlah kelompok masyarakat di Jepara memiliki cara yang khas untuk mengungkapkan makna leksikon 'pergi' dalam budayanya. Arti leksikon 'pergi' dalam KBBI 'berjalan' atau 'bergerak maju', 'meninggalkan' suatu tempat, dan 'berangkat'. Keunikan cara pengungkapkan leksikon 'pergi' mencerminkan keragaman realitas dan budaya yang melatarbelakangi. Salah satu kelompok masyarakat tutur yang menggunakan varian makna leksikon 'pergi' adalah masyarakat pesisir Jepara, Jawa Tengah. Mereka mengenal berbagai leksikon 'pergi', seperti minggat, menyang, budal, tindak (krama inggil), lunga, kesah (krama madya), mbedal, mlancong, cabut, menyat, dan dumugi. Leksikon-leksikon tersebut mempunyai makna yang khas bagi masyarakat asli perisir Jepara yang masih memegang teguh nilai-nilai kearifan lokalnya.

Penelitian ini bertujuan untuk mengklasifikasikan leksikon 'pergi' sesuai dengan konteks dan pengguna bahasanya. Oleh karena itu, dalam menganalisis, penulis menggunakan pijakan semantik/ makna dan budaya. Frawley (1992:138) menjelaskan pendekatan semantik di antaranya meanning as reference (makna sebagai referensi), meaning as logical form (makna sebagai bentuk logika), meaning as context and use (makna sebagai konteks dan penggunaan), meaning as culture (makna sebagai budaya), dan meaning as conceptual structure (makna sebagai struktur konseptual). Dalam penelitian ini, penulis mengembangkan leksikon 'pergi' berdasar makna sebagai konteks dan penggunaan dalam budaya tutur di masyarakat pesisir Jawa.

Kajian fungsi bahasa mengacu pada konsep bahasa Leech (dalam Usman, 2005: 20) yang mengemukakan lima fungsi bahasa, yaitu: fungsi informasional yaitu fungsi pembawa informasi atau pesan atas tuturan yang disampaikan penutur ke lawan tutur; fungsi ekspresif yaitu fungsi ungkapan perasaan dan sikap penutur yang terealisasi dalam tuturan 
penutur; fungsi direktif yaitu fungsi memengaruhi perilaku atau sikap lawan tutur dapat direalisasikan dalam ujaran tekanan pada lawan tutur untuk mengikuti sesuai yang dikehendaki lawan tutur; fungsi estetik yaitu fungsi penggunaan bahasa demi hasil karya itu sendiri dalam menciptakan nilai artistik, nilai-nilai keindahan yang terealisasi melalui tuturan, dan fungsi fatik yaitu fungsi menjaga hubungan interpersonal antarpenutur dan lawan tutur dalam komunikasi tetap terjalin dengan harmonis.

Haviland (1999:147) mengemukakan bahwa kebudayaan diciptakan oleh sekelompok masyarakat yang membentuk peraturan atau norma yang untuk dikesepakati bersama anggotanya. Dalam sekelompok masyarakat budaya, memiliki aturan atau norma budaya yang berbeda. Norma budaya yang telah disepakati bersama akan menjadi budaya baru. Mahsun (200:159) menyebutkan kebudayaan terdiri atas nilai-nilai kepercayaan, persepsi masyarakat, perilaku komunikasi yang tercermin aktivitas manusia. Hal serupa juga dikemukakan oleh Saryono (1997: 38) bahwa nilai budaya merupakan hal yang abstrak. Tidak dapat diukur dengan statistik tetapi wujud riil budaya dapat dilihat dari perilaku manusia dalam berkomunikasi dan berinteraksi dengan sesamanya. Nilai budaya hanya bisa diketahui melalui pemahaman dan penafsiran tindakan, perbuatan, dan tuturan manusia. Nilai budaya menjadi aturan dalam berinteraksi di masyarakat. Nilai budaya menjadi sumber aturan hidup dalam dalam berinteraksi di masyarakat secara individual, sosial, dan religius untuk dapat menciptakan keharmonisan hidup masyarakat.

Berdasar beberapa pandangan di atas, nilai budaya dapat direalisasikan melalui sistem gramatikal dan leksikon yang terealisasi melalui leksikon-leksikon bahasa Nusantara. Penutur Jawa memiliki cara pandang dalam komunikasi antarpenutur. Cara pandang tersebut terealisasi melalui leksikon-leksikon yang digunakan. Pemilihan leksikon dalam bahasa Jawa yang digunakan oleh penuturnya, mencerminkan tingkat kepribadian penutur. Bahasa Jawa memiliki perbedaan signifikan dalam pemaknaan leksikon dibanding dengan bahasa Nusantara lainnya. Bahkan dalam bahasa Jawa sendiri memiliki perbedaan asosiasi makna yang mencerminkan nilai-nilai yang perilaku dalam masyarakat dan budaya Jawa. Sebagai contoh, proses pemerolehan unsur-unsur kebahasaan yang berupa unsur leksikon dalam bahasa Jawa menunjukan keberagaman leksikon Jawa. Keragaman leksikon tersebut secara otomatis mengakibatkan perubahan sistem gramatikal. Dalam bahasa Jawa sistem 
pembentukan waktu secara simultan pula telah tertanam cara pandang masyarakatnya. Kekayaan leksikon dalam bahasa Jawa sebagai cerminan keberagaman budaya yang dimiliki masyarakat Jawa. Hal ini sejalan dengan pendapat Sapir dalam Simanjuntak (2009: 115) bahwa tiap-tiap bahasa suatu masyarakat telah mendirikan sebuah dunia tersendiri untuk penutur bahasa itu. Sebanyak bahasa masyarakat-masyarakat dunia, sebanyak itulah dunia dibentuk oleh bahasa-bahasa itu untuk penutur-penuturnya.

Wierzbicka (1997:179) mengemukakan bahwa leksikon mencerminkan dan menceritakan karakteristik cara hidup dan cara berpikir penuturnya dan dapat memberikan petunjuk yang sangat bernilai dalam upaya memahami budaya penuturnya. Demikian juga dengan leksikon yang terkandung pada makna leksikon 'pergi' dalam bahasa Jawa, leksikon tersebut dapat memberikan dan mencerminkan gambaran tentang pandangan orang pesisir Jepara terhadap lingkungan dan pola berpikirnya. Leksikon 'pergi' sebagai salah satu jenis leksikon dalam bahasa Indonesia yang memiliki fenomena kebahasaan di dalam bahasa Jawa khususnya daerah pesisir Jepara yang menarik untuk dikaji. Leksikon

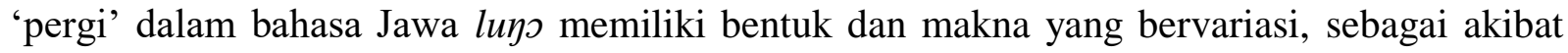
fungsi bahasa yang beragam. Oleh karena itu, fenomena kebahasaan ini menarik untuk dikaji dari segi pemakaiannya yang dihubungkan dengan latar belakang budaya pemakainya.

\section{Metode Penelitian}

Penelitian ini menggunkan pendekatan kualitatif dengan ranah semantik antropologi. Semantik budaya digunakan dalam penelitian ini, bertujuan untuk mengkaji hubungan bahasa dan kebudayaan di dalam suatu masyarkat. Peranan bahasa sangat dominan dalam mempelajari bagaimana hubungan kultural masyarakat diekspresikan.

Teori semantik antropologi menjadi pisau analisis karena dapat mengupas secara detail bentuk komunikasi masyarakat dalam berkegiatan sosial dan budaya tertentu. Data penelitian berupa tuturan lisan masyarakat pesisir Jepara pada leksikon 'pergi'. Data diambil melalui wawancara kepada perwakilan masyarakat pesisir di wilayah Jepara. Dalam situasi nonformal dan kepada setiap jenjang usia. Setelah data terkumpul dilakukan pengolongan dan pemilahan data yang diperlukan untuk dianalisis menggunakan teori bahasa. Selanjutnya setiap leksikon 'pergi' diinterpretasikan menurut konteks fenomenologis yang ada. 
Penginterpretasian leksikon menggunakan ramah morfologi yakni mengidentifikasi bentuk leksikon sesuai dengan jenis leksikonnya. Tahap berikutnya ditarik simpulan mengenai ketercerminan nilai budaya beserta bentuk lingual dan makna yang terkandung dalam leksikon 'pergi'.

\section{Hasil dan Pembahasan}

Leksikon 'pergi' dalam dialek Jepara dapat dideskripsikan berdasarkan komponen tutur, yakni (1) konteks tuturan, (2) mitra tutur, (3) fungsi tuturan. Berdasarkan klasifikasi yang sudah penulis tetapkan, berikut paparan komponen tutur leksikon 'pergi'.

\section{Leksikon minggat}

Leksikon minggat, memiliki makna 'pergi' dengan konotasi negatif. Konteks tuturan terjadi pada situasi nonformal antarorang dewasa. Seperti pada tuturan berikut:

+: Aku wes suwe ora weruh bojomu

'aku sudah lama tidak melihat suamimu'

-: Mbuh ra ngerti, wes minggat wonge!

'tidak tahu, sudah pergi orangnya!'

Leksikon minggat termasuk dalam bahasa Jawa kasar, yang biasanya muncul dalam umpatan, orang yang sedang marah, dan orang yang sedang bertengkar. Leksikon minggat dalam konteks tuturan tersebut digunakan pada percakapan nonformal antarteman sebaya atau orang yang dianggap dekat. Pemilihan leksikon 'pergi' memiliki fungsi ekspresif, yakni ungkapan sakit hati seorang istri yang sudah lama tidak bertemu dan tidak mendapatkan kabar dari suaminya. Leksikon minggat dipilih karena tingkat rasa sakit hati seorang istri tersebut sudah sangat tinggi. Perilaku tersebut sangat bertentang dengan budaya Jawa, yang sangat menjunjung tinggi derajat perempuan.

\section{Leksikon budal}

Leksikon budal dapat dimaknai berangkat ke suatu tempat atau juga bisa digunakan untuk mengusir segerombolan orang. Leksikon budal digunakan untuk berbicara dengan orang yang lebih tua, dengan teman sederajat dan dengan orang yang dianggap dekat secara personal. Jadi leksikon budal ini bisa digunakan dengan siapa saja bergantung pada kesepakatan budaya di wilayah tersebut.

Wes, budal-budal! 
'sudah, pergi-pergi!'

Dalam ujaran di atas penggunaan leksikon budal berkaitan dengan konteks pada saat mengusir segerombolan orang yang sedang dalam keadaan bersantai di suatu tempat tanpa tujuan pembicaraan yang jelas. Leksikon budal digunakan pada percakapan antara orang yang sederajat/sebaya. Fungsi bahasa yang terdapat pada tuturan di atas adalah fungsi ekspresif. Pemilihan leksikon budal memiliki fungsi ekspresif dengan maksud memberi penekanan kepada mitra tutur untuk tidak bersantai-santai karena penutur memiliki kegiatan lain di tempat berbeda. Oleh karena itu, leksikon budal sengaja digunakan pada situasi pertuturan dengan teman sebaya.

\section{Bu Susilo budal ning Jakarta esuk mau.}

'Bu Susilo pergi ke Jakarta tadi pagi'

Ada beberapa daerah di Pesisir Jepara yang penggunaan leksikon budal digunakan untuk teman sebaya/sederajat atau orang yang dianggap dekat. Ada juga yang penggunaan leksikon budal sendiri hanya diucapkan untuk orang yang lebih tua. Akan tetapi, leksikon budal ini jarang digunakan di pesisir Semarang. Artinya, tidak semua orang yang ada di daerah pesisir Jepara menggunakan leksikon budal untuk berbicara atau berkomunikasi dengan orang lain. Dalam ujaran di atas penggunaan leksikon budal berkaitan dengan konteks kesepakatan leksikon di suatu tempat dan diucapkan kepada orang yang lebih tua.

\section{Leksikon tindak}

Leksikon tindak berasal dari bahasa Jawa krama inggil digunakan untuk menyebutkan leksikon 'pergi' dalam percakapan sehari-hari. Biasanya digunakan untuk berbicara dengan orang yang lebih tua atau orang yang dihormati.

Ibu tindak pasar nitih dokar.

'Ibu pergi ke pasar naik dokar'

Leksikon tindak pada data di atas memiliki makna 'pergi'. Konteks tuturan yang terjadi pada situasi nonformal untuk penyebutan ke orang tua. Leksikon tindak pada tuturan di atas memiliki konotasi positif dan memiliki fungsi informasional dan fungsi ekspresif. Maksud dari fungsi informasional adalah penutur hanya memberikan informasi ke mitra tutur terkait hal yang diinformasikan, sedangkan fungsi ekspresif adalah penutur memiliki rasa hormat kepada 
mitra tutur dan orang yang dianggap tua sehingga untuk memberikan informasi kepada mitra tutur, penutur menggunakan leksikon dalam bahasa Jawa krama inggil.

\section{Leksikon lunga}

Leksikon lunga dalam bahasa Jawa 'pergi' digunakan dalam percakapan sehari-hari. Leksikon lunga digunakan pada lingkungan percakapan teman sebaya atau dengan orang yang berusia lebih muda. Leksikon lunga termasuk bahasa Jawa yang kasar jadi kurang sopan jika digunakan untuk berbicara dengan orang yang tua.

+: Arep lunga ning ngendi, Rif?

'mau pergi ke mana, Rif?'

-: Aku arep lunga ning sawah, koe melu ora?

'aku mau pergi ke sawah, kamu ikut gak?'

$+:$ Ora

'tidak'

Contoh tersebut menggambarkan situasi yang santai, dibuktikan dengan percakapan antara Joko dan Arif. Jadi, dapat disimpulkan, leksikon lunga termasuk bahasa Jawa kasar jika digunakan untuk berbicara dengan orang yang lebih tua. Begitu pula sebaliknya, leksikon lunga jika digunakan dengan teman sebaya atau orang yang lebih muda akan menghasilkan situasi yang santai.

\section{Kesah}

Penggunaannya hampir sama dengan leksikon tindak, namun leksikon kesah termasuk bahasa Jawa krama madya yang lebih banyak digunakan dalam percakapan sehari-hari antara orang yang lebih muda kepada orang yang lebih tua.

Perbedaan penggunaan leksikon tindak dan leksikon kesah lebih kepada subjeknya dalam bahasa Jawa disebut wasesa. Leksikon tindak lebih banyak digunakan jika subjeknya adalah orang yang dihormati dan dalam percakapan Jawa yang lebih formal. Perbedaan penggunaan leksikon tindak dan kesah dalam sebuah percakapan:

a. Penggunaan leksikon tindak

+ Guru : : Panjenengan ajeng tindak dateng pundi, Pak?

'Anda mau pergi kemana, Pak?'

-Kepsek : : Oh, kula ajeng tilik sedulur teng griya sakit sekedap, Bu. 
'oh, saya mau pergi menjenguk saudara di Rumah Sakit sebentar, Bu.

b. Penggunaan leksikon 'kesah'

+Pakde : Ibumu lunga ning endi, Le?

'ibu kamu pergi ke mana, Nak?'

-Henri : Kesah teng nggene simbah, Pakde

'pergi ke rumah nenek, Pakde'

\section{Menyang}

Leksikon menyang biasanya digunakan untuk menjawab sebuah pertanyaan dan jarang sekali digunakan untuk sebuah kata tanya di pesisir Jawa. Leksikon menyang diduga merupakan leksikon yang mengalami perluasan persebaran pemakaian. Berdasar bentuk leksikonnya, leksikon menyang merupakan leksikon khas dari Jawa Tengah daerah selatan (Solo). Migrasi masyarakat pada waktu dulu berakibat penyebaran leksikon tertentu yang dianggap produktif oleh budaya masyarakat, sehingga pada kelompok budaya tertentu leksikon tersebut tetap dipertahankan. Leksikon menyang digunakan pada situasi pembicaraan antara penutur dengan mitra tutur yang lebih tua. Leksikon menyang termasuk ke dalam bahasa Jawa kromo madya. Fungsi yang ada pada tuturan di atas adalah fungsi ekspresif.

\section{Ibu : Kowe meh ning endi, Nok?}

'kamu mau ke mana, Dek?'

Nita : Aku meh menyang pasar, Bu.

'aku mau pergi ke pasar, Bu.'

\section{Mbedal}

Leksikon mbedal digunakan dalam percakapan antarpenutur yang sudah akrab. Leksikon mbedal termasuk ke dalam bahasa Jawa ngoko kasar. Kasar bermakna jika digunakan untuk berbicara dengan orang yang lebih tua, rasanya tidak pantas dan kurang sopan. Fungsi ekspesif sangat terlihat pada tuturan tersebut. Mitra tutur memilih leksikon mbedal dengan tujuan ingin mengungkapkan rasa tidak suka orang tuanya (orang tua Rina) atas kelakuan anak perempuannya (Rina) yang pergi tanpa pamit dengan teman-temannya yang memiliki pergaulan tidak baik.

Rina gek wae mbedal karo kancane. 
'Rina baru saja pergi dengan temannya'

\section{Mlancong}

Leksikon mlancong hampir sama dengan leksikon mbedal, perbedaannya pada konotasi maknanya. Leksikon mlancong lebih sopan dibandingkan leksikon mbedal. Kedua leksikon tersebut merupakan bahasa Jawa yang kasar. Leksikon mlancong digunakan untuk berbicara dengan sesama teman baik yang sudah akrab maupun belum. Penggunaan leksikon mlancong sendiri termasuk leksikon yang santai untuk berkomunikasi dengan sesama. Jadi, penggunaan leksikon mlancong dengan teman yang belum akrab pun akan terlihat seperti sudah akrab/dekat.

Contoh:

Aku mlancong bareng kancaku ning Yogya.

'Aku pergi dengan temanku ke Yogya'

\section{Menyat}

Dalam percakapan sehari-hari konteks yang terbangun di masyarakat leksikon menyat memiliki arti 'bangun' bukan 'pergi'. Akan tetapi di daerah pesisir leksikon menyat memiliki arti 'pergi'. Leksikon menyat sendiri digunakan pada saat orang merasa bosan dan sedikit marah. Perbedaan leksikon menyat yang memiliki arti 'bangun' dan 'pergi' terdapat pada situasi dan kondisi suatu kejadian.

a. Leksikon menyat yang memiliki arti pergi

Wawan : Wes lah aku meh menyat wae, daripada aku ning kene ora diperlukke.

'Sudahlah aku mau pergi saja, daripada aku di sini tidak diperlukan'

b. Leksikon menyat yang memiliki arti bangun.

Digunakan pada saat situasi orang yang sedang duduk dan berdiri atau bangun dari duduknya. Kemudian juga bisa digunakan pada saat seseorang yang sedang tidur kemudian bangun dari tempat tidurnya.

Ibu : bocah kok ora menyat-menyat ki pie, wes jam piro iki, mengko telat mangkat sekolahe.

'anak ini kok gak bangun-bangun itu gimana, sudah jam berapa ini, nanti terlambat berangkat sekolahnya'. 
Berdasarkan hasil wawancara mendalam di daerah pesisir, didapat hasil bahwa penggunaan leksikon tindak dan lunga terdapat di seluruh daerah pesisir. Semua masyarakat menggunakan leksikon tindak digunakan ketika dalam konteks bahasa Jawa (krama alus) dan lunga digunakan dalam konteks bahasa Jawa 'pergi' ketika berkomunikasi dengan orang lain. Kemudian leksikon minggat, budal, kesah digunakan dalam konteks bahasa Jawa krama madya, dan menyang, mayoritas digunakan untuk komunikasi oleh masyarakat pesisir. Terakhir ialah leksikon mbedal, mlancong, menyat. Leksikon tersebut sangat jarang diucapkan oleh masyarakat pesisir. Hanya pada konteks tuturan tertentu saja leksikon tersebut digunakan.

\section{Simpulan}

Salah satu kelompok etnik yang memiliki makna leksikon yang unik tentang 'pergi' adalah masyarakat pesisir Jepara. Mereka mengenal berbagai leksikon 'pergi', seperti minggat, menyang, budal, tindak, lunga, kesah, mbedal, mlancong, menyat. Leksikon 'pergi' dalam bahasa Jawa mempunyai makna tersurat dan tersirat. Makna tersuratnya adalah makna leksikon 'pergi' yang dapat dilihat dalam kamus, sedangkan makna tersirat adalah makna yang dapat ditelusuri dengan melihat konteksnya. Berdasarkan analisis data, leksikon 'pergi' dalam bahasa Jawa memiliki beberapa makna tersirat. Makna antropologis leksikon 'pergi' dibedakan atas:(1) konteksnya, (2) mitra tutur, (3) penguasaan bahasa penutur dan mitra tutur, dan (4) tingkat pendidikan penutur dan mitra tutur.

\section{Daftar Pustaka}

Fawley, William. 1992. Linguistic Semantic. New Jersey: Lawrence Erlbaum Associates.

Haviland, William A. 1999. Antropologi. Edisi Keempat, Jilid I. Jakarta: Penerbit Erlangga.

Kamus Besar Bahasa Indonesia. 2008. Edisi keempat. Jakarta: PT Gramedia Pustaka Utama.

Mahsun. 2001. Metode Penelitian Bahasa. Jakarta: Raja Grafindo Persada.

Saryono, Dj. 1997. "Representasi Nilai Budaya Jawa dalam Prosa Fiksi Indonesia". Disertasi. Malang: Universitas Negeri Malang.

Simanjuntak, Mangantar. 2009. Pengantar Neuropsikolinguistik. Medan: Perpustakaan Nasional RI. 
Usman, Fajri. 2005. "Metafora Dalam Mantra Minangkabau". Tesis Program Pascasarjana. Bali. Universitas Udayana.

Wierzbicka, Anna. 1997. Understanding CuAltures Through Their Key Words: English Russian, Polish German, and Japanese. Newyork: Oxford University Press. 